\title{
Regulation of planktonic ciliate dynamics and functional composition during spring in Lake Constance
}

\author{
Katrin Tirok*, Ursula Gaedke \\ University of Potsdam, Institute of Biochemistry and Biology, Department of Ecology and Ecosystem Modelling, \\ Am Neuen Palais 10, 14469 Potsdam, Germany
}

\begin{abstract}
Protozoans are among the most important grazers of phytoplankton and remineralizers of nutrients in marine and freshwater ecosystems, but less is known about the regulation of their population dynamics. We analyzed a 12 yr data set of ciliate biomass and species composition in large, deep Lake Constance to understand the factors influencing ciliate spring development. The start of ciliate net growth in spring was closely linked to that of edible algae, chlorophyll $a$ and the vertical mixing intensity, but independent of water temperature. During ciliate spring growth, the relative contribution of ciliated interception feeders was positively related to that of cryptomonads, whereas the relative contribution of filter feeders correlated positively with that of non-cryptomonads. The duration of ciliate dominance in spring was largely controlled by the highly variable onset of the phytoplankton bloom, as the termination of the ciliate bloom was less variable. During years with an extended spring bloom of algae and ciliates, internally forced species shifts were observed in both communities. Interception feeders alternated with filter feeders in their relative importance as did cryptomonads and non-cryptomonads. Extended spring blooms were observed when vertical mixing intensity was low at low temperatures during early spring, which will become less likely under the anticipated climate change scenarios. The termination of the ciliate spring bloom occurred prior to a reduction in food concentration and mostly also prior to the mass development of daphnids alone, but coincided with increased grazing by various predators together, such as rotifers, copepods and daphnids in late May/early June.
\end{abstract}

KEY WORDS: Plankton spring succession · Species shift · Predator-prey relationship · Deep lake · Edible algae $\cdot$ Climate change

\section{INTRODUCTION}

Seasonal plankton succession in temperate lakes is controlled by complex interplay between physical and chemical variables and food web interactions (Sommer et al. 1986). It is well known that phytoplankton succession in spring depends on light availability, whereas crustaceans depend strongly on temperature (Straile 2000, Benndorf et al. 2001, Lee et al. 2003). However, less is known about the regulation of protozoans, although they are among the most important grazers of phytoplankton (Müller et al. 1991, Gaedke \&
Straile 1994, Neuer \& Cowles 1994) and remineralizers of nutrients (Sonntag et al. 2006) in marine and freshwater ecosystems.

In Lake Constance, ciliates dominated the herbivorous zooplankton in spring, prior to the clear-water phase towards which their biomass strongly declined (e.g. Müller et al. 1991, Weisse \& Müller 1998). They are known to feed mainly on phytoplankton during spring (Müller et al. 1991, Gaedke et al. 2002).

Spring phytoplankton development was linked to large-scale meteorological phenomena like the North Atlantic Oscillation (NAO, quantified as NAO index) in 
several European lakes, whereby years with a high NAO index showed an early ice-off and vice versa (Weyhenmeyer et al. 1999, Gerten \& Adrian 2000). This mechanism is irrelevant for non-ice-covered lakes, such as Lake Constance, where phytoplankton spring development was dependent on the intensity of vertical mixing (Gaedke et al. 1998a, Peeters et al. 2007) and global irradiance (Tirok \& Gaedke 2007). Vertical mixing, in turn, was driven in a complex way by episodic wind events during early spring (Bäuerle et al. 1998). Thus, the NAO index and individual meteorological parameters, such as the average air temperature or wind speed, were not linked to phytoplankton spring development in Lake Constance (Gaedke et al. 1998b, Straile 2000). Epilimnetic phytoplankton biomass increased as soon as the vertical mixing intensity was low, and light conditions were suitable even if this occurred as early as February and at water temperatures around 4 to $5^{\circ} \mathrm{C}$. Vice versa, epilimnetic algal biomass always remained low or decreased at high mixing intensities owing to the dilution effect throughout the water column and the insufficient underwater light climate.

In contrast, the development of crustaceans, i.e. cladocerans and copepods, depended strongly on temperature (Straile \& Geller 1998a, Lee et al. 2003), and several studies showed their importance as predators and intraguild predators of ciliates (Jack \& Gilbert 1997, Burns \& Schallenberg 2001). In Lake Constance, copepods dominated the crustacean community during early spring, whereas daphnids peaked in late spring/early summer (Straile \& Geller 1998b). Interannual differences in spring Daphnia development were strongly linked to interannual differences in water temperature, which, in turn, were closely related to the variability in the NAO (Straile 2000). Hence, the onset of phytoplankton and crustacean spring growth is controlled by different factors, i.e. wind-induced vertical mixing versus water temperature, in Lake Constance. Both groups of organisms may exert a decisive influence on ciliate development and are presumed to be influenced by the ongoing climate change. Climate models predict a substantial warming during winter and spring ( 1 to $5.5^{\circ} \mathrm{C}$ ) and increases in storm activity in western and central Europe (IPCC 2001, Giorgi et al. 2004, Leckebusch \& Ulbrich 2004). Recent studies have already shown that climate change strongly influences phenology and trophic interactions in pelagic communities (Edwards \& Richardson 2004, Winder \& Schindler 2004). This raises the question as to how ciliate spring dynamics respond to altered climatic conditions.

In addition, ciliate species composition is known to be linked to season and to prey availability. Its alteration was described in connection with shifts in prey types, e.g. from algae to bacteria and heterotrophic flagellates, the change of seasons or sampling location and depth (Müller et al. 1991, Samuelsson et al. 2006, Sonntag et al. 2006). Numerous ciliate species are known to feed selectively on small phytoplankton (Verity 1991, Hamels et al. 2004). The phytoplankton spring bloom in Lake Constance is dominated by the cryptomonads Rhodomonas spp. and Cryptomonas spp. and the small centric diatom Stephanodiscus parvus (Kümmerlin 1991, Sommer et al. 1993). A strong negative selection for small diatoms was described in a ciliated interception feeder, but not in a filter feeder for Lake Constance (Müller \& Schlegel 1999). Hence, ciliate species composition may depend on algal composition.

In the present study, we analysed 12 yr of measurements of ciliate spring dynamics in Lake Constance (1987 to 1998) in relationship to the spring development of phytoplankton, rotifers and crustaceans, and to the spring warming and vertical mixing of lake water. In contrast to the above-mentioned studies, which used a coarser scale, we considered a fine scale by analysing short-term species shifts within 1 prey type (algae) and within the algivorous ciliate community during 1 season (the spring bloom). We show that: (1) ciliate spring growth follows the algal spring growth with a time lag of approximately $1 \mathrm{wk}$, independent of spring warming; (2) the termination of the ciliate bloom in late spring/early summer is attributable to grazing and intraguild predation of various predator groups; (3) ciliated filter feeders benefit from a high quantity of mixed food algae, including small centric diatoms, in contrast to interception feeders, which depend on high-quality cryptomonads, which are sometimes less abundant.

\section{MATERIALS AND METHODS}

Study site. Upper Lake Constance is a large (area = $472 \mathrm{~km}^{2}$, volume $\left.=48 \mathrm{~km}^{3}\right)$, deep $\left(z_{\text {mean }}=101 \mathrm{~m}, z_{\max }=\right.$ $252 \mathrm{~m})$, warm-monomictic lake north of the European Alps. Lake Constance underwent re-oligotrophication from 1979 onwards (total phosphorus during winter circulation $=87 \mu \mathrm{g} \mathrm{Pl}^{-1}$ in 1979 and $17 \mu \mathrm{g} \mathrm{Pl}^{-1}$ in 1998), and its trophic state changed from meso-eutrophic to more oligotrophic conditions.

Sampling. Plankton sampling was carried out weekly during the growing season and approximately every $2 \mathrm{wk}$ in winter at the deepest point in Überlinger See $(147 \mathrm{~m})$, the north-western part of the lake. Phytoplankton and crustaceans were sampled from 1979 to 1998 (except 1983), ciliates from 1987 to 1998, and rotifers from 1984 to 1996 (except 1985 and 1986). The abundance of phyto- and zooplankton was assessed 
using standard microscope techniques (Müller 1989, Straile \& Geller 1998b, Gaedke et al. 2002, and literature cited therein), and cellular abundances were converted into biomass according to Weisse \& Müller (1998) and Gaedke et al. (2002). Average values of the uppermost $20 \mathrm{~m}$ were considered in the present study, which roughly correspond to the epilimnion and the euphotic zone (Tilzer \& Beese 1988), i.e. values per $\mathrm{m}^{2}$ correspond to $20 \mathrm{~m}^{-3}$. Chlorophyll a concentrations were measured from 1980 to 1998 using hot ethanol extraction (Häse et al. 1998). Primary production was measured in situ from 1980 to $1997\left({ }^{14} \mathrm{C}\right.$-fixation, $4 \mathrm{~h}$ of incubation; Häse et al. 1998).

Algal and ciliate morphotypes. Phytoplankton and ciliates were grouped into morphotypes that represent either individual species or higher taxonomic units, which were distinguished morphologically and consistently assessed throughout the study period (Müller 1989, Gaedke 1998, Gaedke \& Wickham 2004).

Analyses at the population level were restricted to the 5 most important edible phytoplankton morphotypes in spring ( $84 \%$ of edible algal biomass) and the 9 most important ciliate morphotypes in spring (88\% of total ciliate biomass) (Table 1). Edible phytoplankton are typically fast-growing, small, unicellular nanoplankters (e.g. small phytoflagellates) and small centric diatoms based upon their shape, size, defence tactics, and susceptibility to grazing pressure mainly by cladocerans (Knisely \& Geller 1986). Ciliates differ in their feeding behaviour and were thus grouped according to whether they are primarily interception

Table 1. Taxonomy, cell volume of individual cells, relative contribution to total biomass and feeding type (only ciliates) for the most important edible phytoplankton and ciliate morphotypes, which were included in the analysis. Filt: filter feeders; Int: interception feeders. Two cell volumes for 1 morphotype refer to 2 size types within this morphotype

\begin{tabular}{|llccc|}
\hline Code & Morphotype & $\begin{array}{c}\text { Total biomass }(\%) \\
\text { Jan-May 1987-1998 }\end{array}$ & $\begin{array}{c}\text { Cell vol. } \\
\left(\mu \mathrm{m}^{3}\right)\end{array}$ & $\begin{array}{c}\text { Feeding } \\
\text { type }\end{array}$ \\
\hline Edible phytoplankton & & & & \\
RHO & Rhodomonas spp. & 40 & $90 / 300$ & \\
STH & Stephanodiscus parvus & 21 & 50 & \\
CRY & Cryptomonas spp. & 15 & $1600 / 2100$ & \\
$\mu$ Alg & Small eukaryotic algae & 5 & $5 / 33$ & \\
CHL & Chlamydomonas spp. & 3 & $25 / 400$ & \\
Ciliates & & & & \\
TIN & Tintinnids & 17 & 24000 & Filt \\
HIS & Histiobalantium bodamicum & 14 & $34000 / 68000$ & Int \\
STR & Limno-/pelagostrombidium & 14 & $32000 / 77000$ & Filt \\
RLAC & Rimostrombidium lacustris & 14 & 119000 & Filt \\
OLI & Oligotrichs < 35 $\mu$ m & 12 & $2700 / 6500$ & Filt \\
BAL & Balanion planctonicum & 7 & 1300 & Int \\
ASK & Askenasia sp. & 4 & $7200 / 37000$ & Int \\
PD & Peritrichs on diatoms & 3 & $10000 / 37000$ & Filt \\
UF & Urotricha furcata & 3 & 1700 & Int \\
& & & & \\
\hline
\end{tabular}

or filter feeders following Gaedke \& Wickham (2004) (Table 1). Interception feeders capture and process single prey particles, whereas filter feeders strain suspended food particles from surrounding water. Ciliate predators are represented by daphnids (Daphnia hyalina and D. galeata), cyclopoid copepods (mostly Cyclops vicinus and Mesocyclops leuckarti), calanoid copepods (Eudiaptomus gracilis), predacious rotifers (Asplanchna priodonta) and mostly large ciliates that graze, e.g. on small ciliates (e.g. Askenasia spp., Didinium spp., Stentor sp.).

Environmental parameter. Water temperature was recorded at various depths at the respective sampling dates in 1979, 1980, 1981 and 1986 and logged every 20 min during the other years until 1998, except 1993. We used the winter index of the NAO (December through March), which is based on the difference of normalised sea level pressures between Lisbon, Portugal, and Stykkisholmur, Iceland, as provided by the National Centre of Atmospheric Research, Boulder, Colorado, USA (www.cgd.ucar.edu/cas/catalog/). It correlated positively with the water temperature in Lake Constance in winter and in spring (Straile et al. 2003).

Vertical mixing intensity was inferred from a 1-dimensional, numerical, k-epsilon hydrodynamic model simulating the turbulent transports of momentum, heat and mass in the water column (Bäuerle et al. 1998). These are induced by the direct influence of the wind at the lake's surface, by short- and long-wave radiation, and by the fluxes of latent and sensible heat. The model was driven by the observed meteorological conditions, such as air temperature, wind speed and direction, humidity, cloud cover and solar radiation, and reproduced the observed temperature profiles. The model estimated a vertical exchange rate for the years 1979 to 1995 , which represents deep mixing and is defined as the proportion of a tracer that is transported from the 0 to $8 \mathrm{~m}$ layer to the 20 to $100 \mathrm{~m}$ layer (Gaedke et al. 1998c). It is assumed that phytoplankton and small herbivores are passively transported. In Lake Constance, mixing intensity can occasionally be very low during calm periods, even in the absence of stratification (Bäuerle et al. 1998).

Statistical analysis. Net community growth of ciliates was observed during March in most years. Hence, to reveal general factors influencing ciliate spring growth, values of total ciliate 
biomass, edible algal biomass, primary production, chlorophyll $a$, temperature and vertical mixing intensity were averaged over March and the NAO winter index was used. The variability in the ciliate biomass explained by the above-named variables was derived from linear regression analyses. As the independent variables were highly correlated to each other in March, except for the NAO winter index, individual rather than multiple regression analyses were calculated. Biomasses of edible algae and ciliates, chlorophyll $a$ and primary production were log-transformed prior to the regression analyses, and the coefficient of determination was denoted by $\mathrm{r}^{2}$. In addition, correlations between the 2 main ciliate feeding types (interception feeders and filter feeders), and the edible algal groups (cryptomonads: Rhodomonas spp., Cryptomonas spp.; non-cryptomonads: Stephanodiscus parvus, Chlamydomonas spp., small eukaryotic algae) were investigated during spring growth. We calculated Spearman's rank correlation coefficients, denoted by $\mathrm{r}$, with algal and ciliate biomasses averaged over March.

The period from April to mid-May represented the spring bloom during most years. To identify interactions between individual ciliate and edible algal morphotypes during the spring bloom, we calculated correlations using Spearman's rank correlation coefficient based on all sampling dates of this period.

The spring bloom was followed by a decline in ciliate biomass. The timing of the ciliate decline was defined as the first strong decrease in ciliate biomass after reaching peak biomass (approximately a factor of $\geq 2$ ). To explain the variability in the timing of the ciliate decline, we related it to the timing of the decline in algal biomass (decrease of approximately a factor of $\geq 2$ after reaching peak biomass) and the timing when predators reached high biomasses by performing linear regression analyses. Daphnids exerted pronounced intraguild predation on ciliates when their biomass surpassed 25-50 $\mathrm{mg} \mathrm{m}^{-3}$ (corresponding to 500-1000 $\mathrm{mg} \mathrm{C} \mathrm{m}^{-2}$ in a $20 \mathrm{~m}$ water column as considered in the present study) (Jürgens 1994, Gaedke \& Straile 1998, Tittel et al. 1998, Weisse \& Müller 1998). Thus, to investigate the effect of daphnids on the timing of the ciliate decline, the date when daphnids reached $500 \mathrm{mg} \mathrm{C} \mathrm{m}^{-2}$ was used in the regression analyses. Spearman's rank correlation coefficients were calculated between temperature and biomass of daphnids using mean values for May.

Calculations and graphics were performed with SAS9 (SAS Institute). SD marks the standard deviation.

\section{RESULTS}

In the ciliate community approximately 9 morphotypes contributed significantly to total ciliate biomass in spring, but no ciliate species dominated consistently (Table 1). In contrast, in the algal community 5 algal morphotypes contributed significantly to the edible algal community and 3 of them dominated the community.

\section{Ciliate spring growth and spring bloom}

The early spring development of ciliates, which typically occurred during March, was closely coupled with algal dynamics (Table 2). In March, mean ciliate biomass was significantly related to mean edible algal biomass, primary production and chlorophyll a concentrations (Table 2). Mean epilimnetic ciliate biomass in March was also related to the intensity of vertical mixing during this month, but not to water temperature or the NAO winter index (Table 2). Even during years with early algal growth, ciliates responded quickly to pulses of their dominant food source despite low water temperatures (i.e. 4 to $7^{\circ} \mathrm{C}$ ). Accordingly, a spring increase in phytoplankton biomass was consistently followed by a corresponding increase in ciliate biomass, with a time lag of about 1 wk during all $12 \mathrm{yr}$ of investigation (Fig. 1). To conclude, the onset of ciliate spring development depended on that of phytoplankton.

Considering the 2 major ciliate feeding types - filter feeders and interception feeders - separately revealed a close relationship between the biomass of the filter feeders with that of non-cryptomonads in March ( $\mathrm{r}=0.90, \mathrm{p}<0.01, \mathrm{n}=12)$, dominated by Stephanodiscus parvus $(\mathrm{r}=0.86, \mathrm{p}<0.01, \mathrm{n}=12)$, but not with that of cryptomonads $(\mathrm{r}=0.39, \mathrm{p}=0.21, \mathrm{n}=$ 12). Likewise, the relative proportion of filter feeders

Table 2. Coefficients of determination from linear regression analyses between mean total ciliate biomass and edible algal biomass (1987 to 1998), primary production (1987 to 1997), chlorophyll a concentration (1987 to 1998), deep vertical mixing intensity (1987 to 1995) and temperature (1987 to 1998) in the upper $20 \mathrm{~m}$ in Lake Constance in March. ns: non-significant; ${ }^{*} \mathrm{p}<0.05,{ }^{* *} \mathrm{p}<0.01,{ }^{* * *} \mathrm{p}<$ 0.001; NAO: North Atlantic Oscillation. For details see 'Materials and methods'

\begin{tabular}{|llcc|}
\hline Dependent variable & Independent variable & $\mathrm{r}^{2}$ & $\mathrm{n}$ \\
\hline & log2(edible algal biomass) & $0.38^{*}$ & 12 \\
& log2(primary production) & $0.68^{* *}$ & 11 \\
log2(ciliate biomass) & log2(chlorophyll a) & $0.78^{* * *}$ & 12 \\
& Vertical mixing intensity & $0.59^{*}$ & 9 \\
& Temperature & $0.24 \mathrm{~ns}$ & 11 \\
& NAO winter index & $0.001 \mathrm{~ns}$ & 12 \\
\hline
\end{tabular}


was positively correlated with that of non-cryptomonads $(\mathrm{r}=0.88, \mathrm{p}<0.01, \mathrm{n}=12)$ in March. In contrast, the biomass of the interception feeders was neither significantly correlated with the biomass of cryptomonads $(\mathrm{r}=0.32, \mathrm{p}=0.31, \mathrm{n}=12)$, nor with that of non-cryptomonads $(\mathrm{r}=0.16, \mathrm{p}=0.62, \mathrm{n}=12)$, whereas their relative proportion was positively correlated with that of cryptomonads $(\mathrm{r}=0.88, \mathrm{p}<0.01, \mathrm{n}=12)$ in March. This reflects that, during the onset of spring growth, filter feeders followed directly the growth of non-cryptomonads, whereas interception feeders were linked to cryptomonads, which developed somewhat later (Fig. 2). This pattern was found within the individual years and also when averaging across the study period.

Considering all sampling dates from January to mid-May (i.e. until the clear-water phase) revealed overall positive correlations between the biomass of both filter and interception feeders and that of total edible algae, Rhodomonas spp. and Stephanodiscus parvus, the scatter of which differed, however, systematically (Fig. 3). Filter feeders always had high biomasses when the total edible algal biomass was high, independent of whether Rhodomonas spp. or

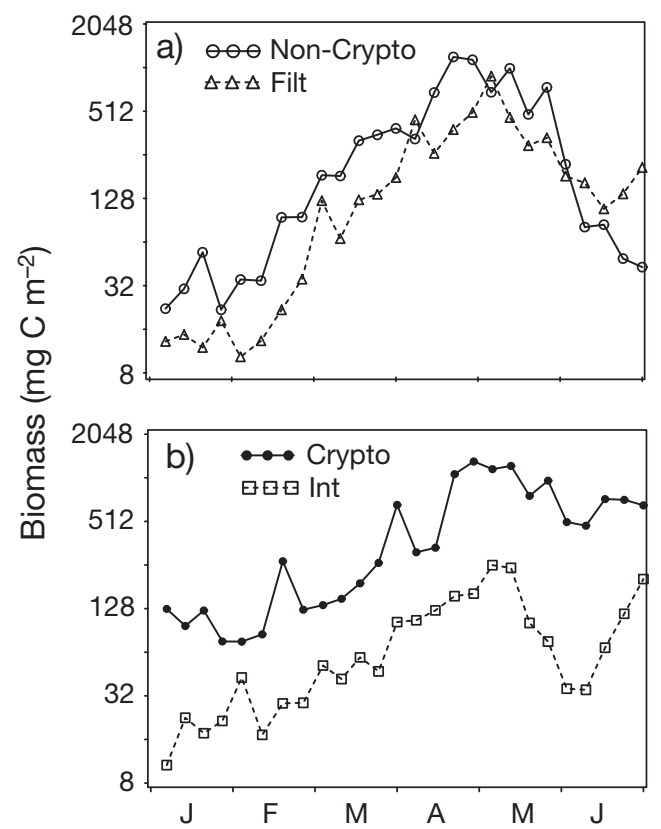

Fig. 2. Mean biomass of (a) non-cryptomonads (Non-crypto) and ciliated filter feeders (Filt) and (b) cryptomonads (Crypto) and ciliated interception feeders (Int) in Lake Constance (1987 to 1998)

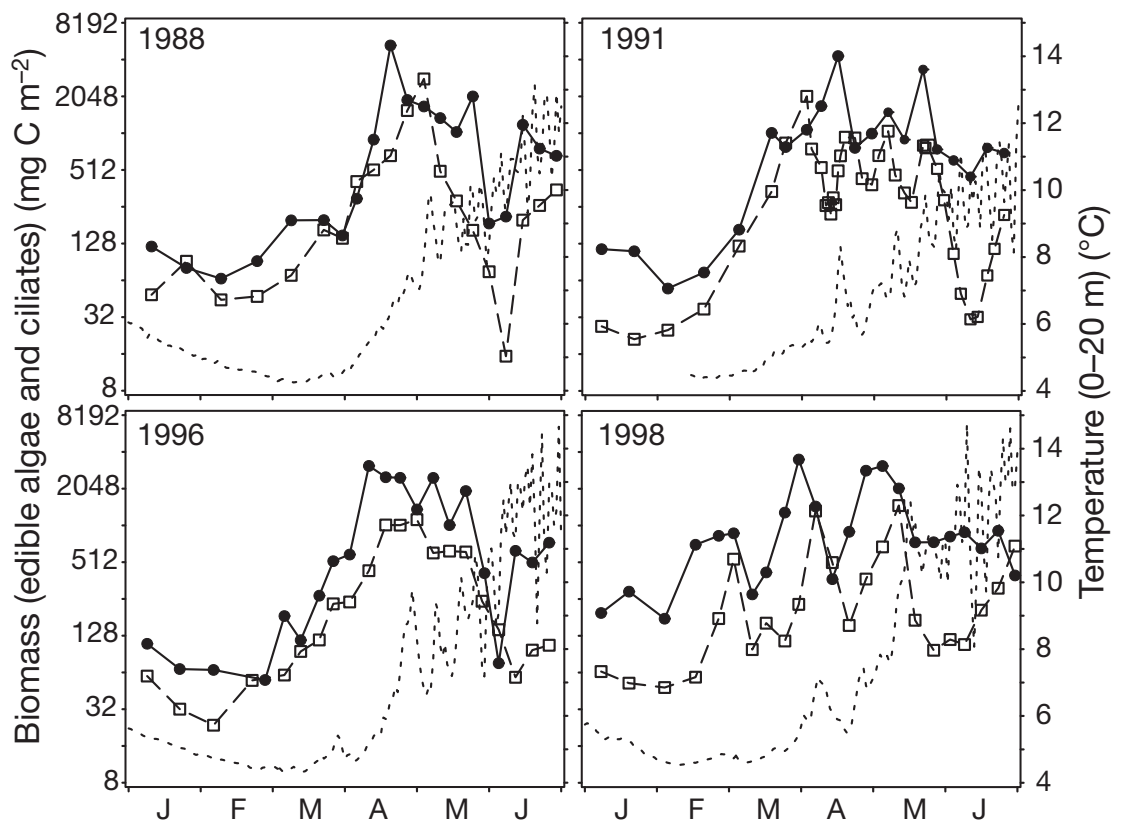

Fig. 1. Phytoplankton (-๑) and ciliate development (----) in spring 1988, 1991, 1996 and 1998 in relation to average water temperature in the upper $20 \mathrm{~m}$ (----). The 4 years were selected out of the $12 \mathrm{yr}$ of investigation to illustrate the large variability in the ciliate peak duration (e.g. 1988 vs. 1991), the tight coupling of algal and ciliate spring growth, in particular, during years with high temporal variability in algal biomass (e.g. 1998) and the potential increase of ciliate biomass prior to a water temperature increase (e.g. 1991, 1996 and 1998). The decline in epilimnetic algal and ciliate biomass in late February and early April 1998 was presumably attributable to pronounced vertical mixing during these periods
Stephanodiscus parvus was dominant (Fig. 3). In contrast, the biomass of interception feeders was either high or low at high edible algal biomass, showing that a high biomass of edible algae alone was not sufficient to support their growth. Their biomass was consistently low at low biomasses of Rhodomonas spp. This supports the above-mentioned link between filter feeders and noncryptomonads, and interception feeders and cryptomonads.

Ciliate peak biomass was reached between the end of March and mid-April and varied little among years (1140 \pm $320 \mathrm{mg} \mathrm{C} \mathrm{m}^{-2}$ ). It was independent of the timing of the onset of ciliate growth and the duration of biomass increase (Fig. 1). After reaching peak biomass, ciliate dynamics varied greatly among years. For example, 1988 was characterised by a rather short phytoplankton development and ciliate bloom, in 1996 a high phytoplankton biomass and a high ciliate biomass was observed throughout April and May, and in, e.g., 1991 and 1998, both phytoplankton biomass and ciliate biomass exhibited cyclical dynamics for several weeks (Fig. 1). 


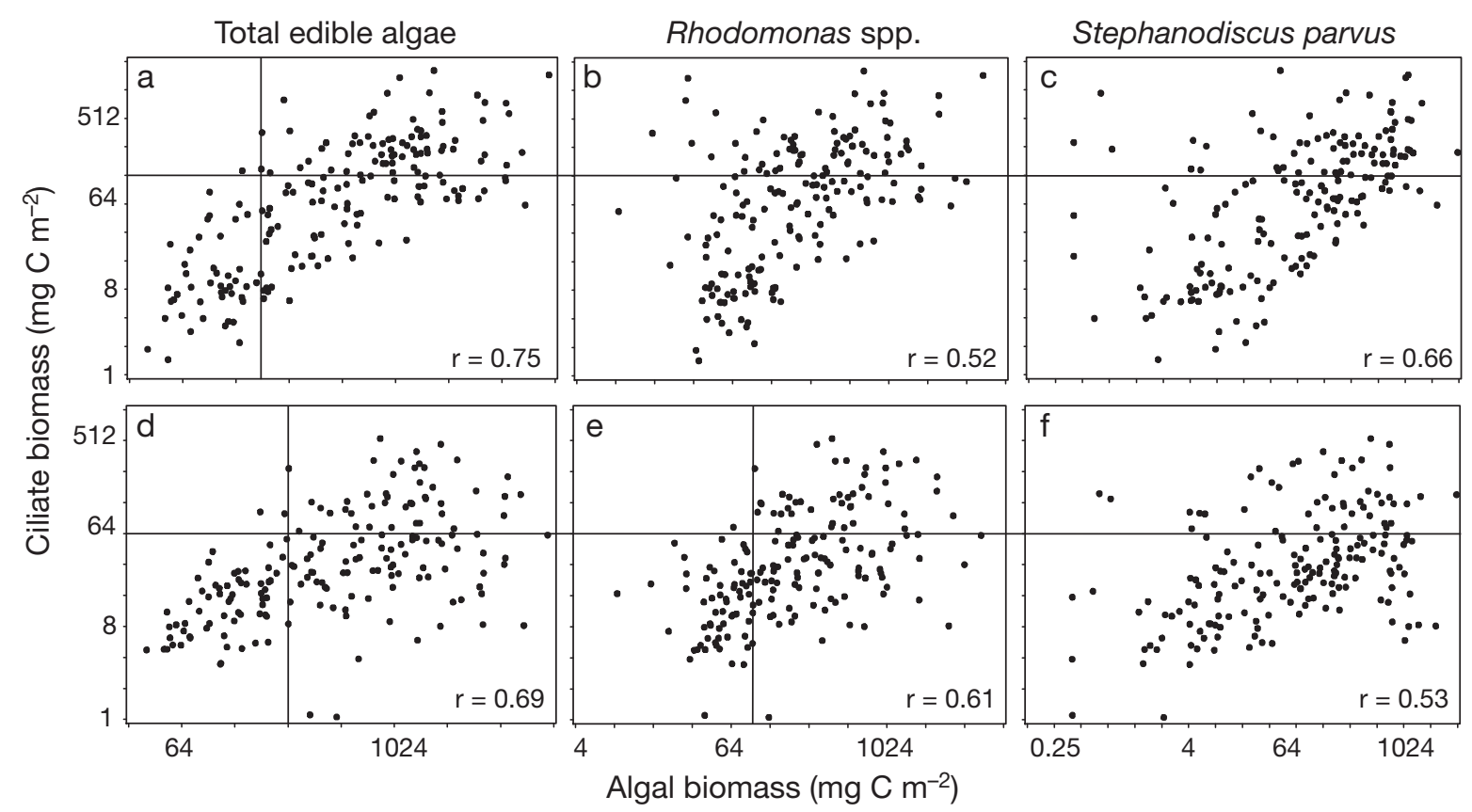

Fig. 3. Correlations between the biomass of $(a-c)$ filter feeders and $(d-f)$ interception feeders and the biomass of $(a, d)$ total edible algae, (b,e) Rhodomonas spp. and (c,f) Stephanodiscus parvus, including all sampling dates from January to mid-May. Note the different scales on the $x$ - and $y$-axes. $r$ : Spearman's rank correlation coefficient; all correlations were significant at the $0.1 \%$ level, $\mathrm{n}=158$

\section{Species shifts during the spring bloom}

During the spring bloom, ongoing alterations in species composition were observed in both the ciliate and edible algal communities (Fig. 4). They were most clearly expressed during years when total ciliate and phytoplankton biomass remained high for many weeks. We did not find a directional shift in species composition from early to late spring, but some species were important during the onset and the end of the bloom, exhibiting low biomasses in between (Fig. 4, e.g. Rimostrombidium lacustris in 1991 and 1996 or Askenasia sp. in 1991).

Several ciliate morphotypes correlated significantly with various algal morphotypes during the spring bloom (Table 3). The scatter within these correlations is relatively high due to the variable duration of the spring bloom during the study period. Higher correlation coefficients were obtained when the period of net growth prior to the bloom was included. Aggregating all ciliate morphotypes into either interception or filter feeders showed that the former were significantly related to cryptomonads, and the latter to non-cryptomonads (Table 3).

In 1991 and 1996, i.e. the 2 years with the longest ciliate spring blooms, a distinct alternation between the relative importance of interception and filter feeders was found, which was also observed in the relative contribution of cryptomonads and non-cryptomonads to edible algal biomass (Fig. 5). This does not correspond to a seasonal succession, as the same groups dominated at the onset and the end of the bloom, but not in between. Furthermore, the patterns of dominance were inversed in the 2 years. These findings are in agreement with the positive correlation between filter feeders and non-cryptomonads and between interception feeders and cryptomonads found during the spring growth and the spring bloom (see above).

\section{Termination of the spring bloom}

The timing of the onset of the decline in phytoplankton and ciliates after the spring bloom was correlated $\left(\mathrm{r}^{2}=0.56, \mathrm{p}<0.01, \mathrm{n}=12\right.$; Fig. 6$)$. However, a strong bottom-up effect has to be questioned, since the onset of the decline in ciliate biomass occurred prior to or at the date when algal biomass started to decline in 10 out of $12 \mathrm{yr}$ and after this date only in 2 out of $12 \mathrm{yr}$ (Fig. 6). The timing of the onset of the ciliate decline was also correlated with the day when daphnid biomass surpassed $500 \mathrm{mg} \mathrm{C} \mathrm{m}^{-2}\left(\mathrm{r}^{2}=0.55, \mathrm{p}<0.01, \mathrm{n}=\right.$ 12; Fig. 6), but again no distinct causal relationship between ciliates and daphnids was found. Daphnid biomass reached $500 \mathrm{mg} \mathrm{C} \mathrm{m}^{-2} 1$ wk before or at the date of the onset of the decline in ciliate biomass in 4 out of $12 \mathrm{yr}$. In the remaining $8 \mathrm{yr}$, daphnids attained relevant biomasses 1 to $3 \mathrm{wk}$ after the beginning of the 
ciliate decline, rendering a strong impact of daphnids on the onset of the ciliate decline unlikely during these years (Fig. 6). No significant relationships between the timing of the decline of ciliate biomass and the timing of high biomasses of calanoid or cyclopoid copepods or of rotifers or ciliates were found. The variability in the timing of the decline of ciliate biomass after the spring bloom was only explicable by considering various predator groups in concert. In numerous years carnivorous rotifers (e.g. 1987), copepods (e.g. 1997) and/or
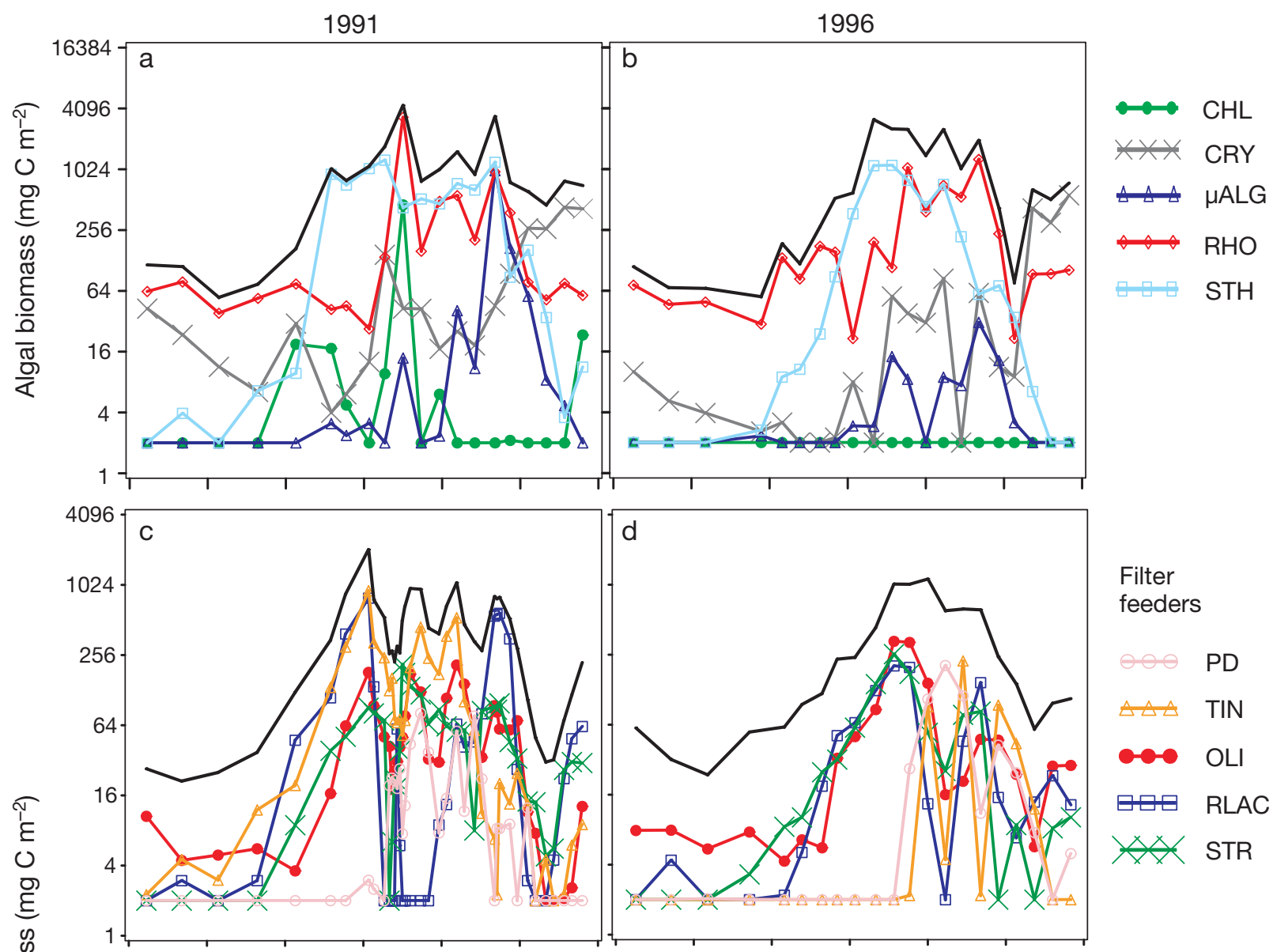

Filter

feeders

$\Leftrightarrow \rho \operatorname{PD}$

$\Delta \Delta \triangle \quad$ TIN

$\leftrightarrow$ OLI

RLAC

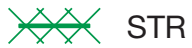
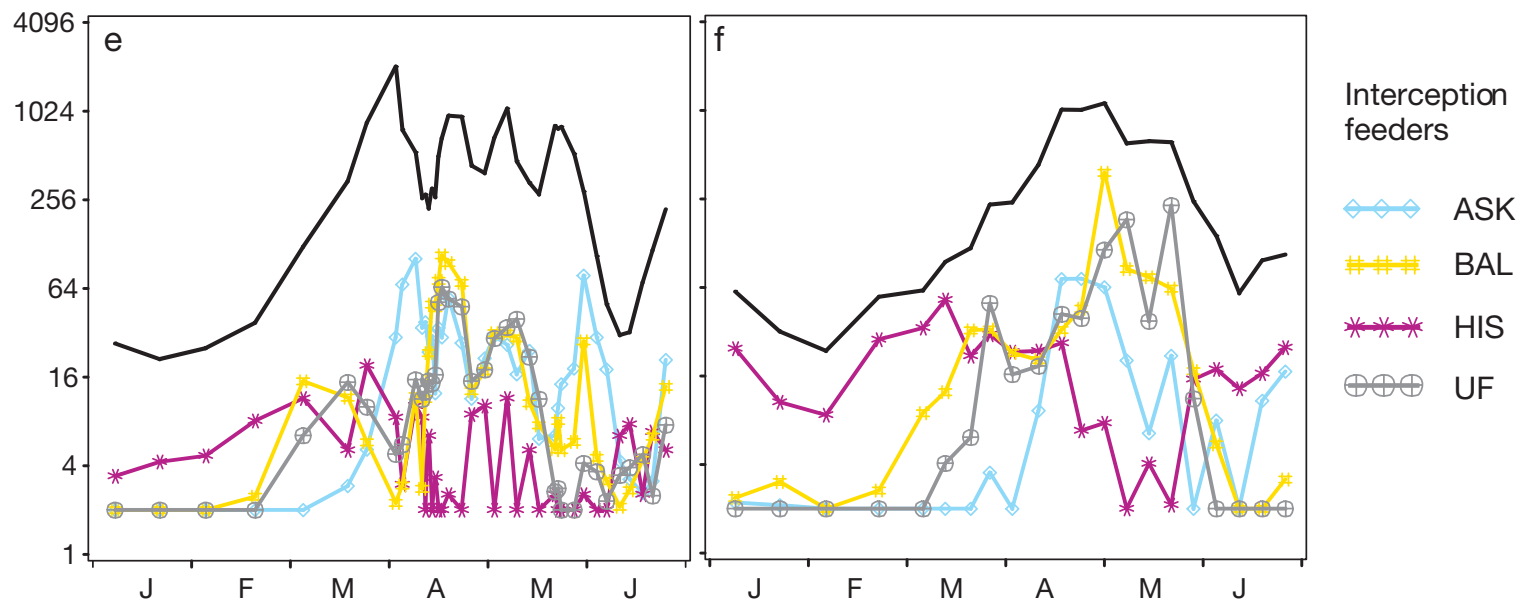

Fig. 4. In situ data of morphotype-specific biomass (coloured lines) and total community biomass (black line) of edible algae $(\mathrm{a}, \mathrm{b})$ and ciliates, with morphotypes split into filter feeders $(\mathrm{c}, \mathrm{d})$ and interception feeders $(\mathrm{e}, \mathrm{f})$ in $1991(\mathrm{a}, \mathrm{c}, \mathrm{e})$ and $1996(\mathrm{~b}, \mathrm{~d}, \mathrm{f}), 2 \mathrm{yr}$ with an extended spring bloom. Total algal and ciliate biomass remained more or less constant during the spring bloom, whereas the morphotype-specific biomasses exhibited partly large fluctuations, indicating compensatory dynamics. For morphotype codes see Table 1 
Table 3. Spearman's rank correlation coefficients of the most important ciliate and edible algal morphotypes during the spring bloom (April to mid-May, Days 91 to 135) in Lake Constance, 1987 to 1998; n = 79, p-values are given in brackets; ns: non-significant. For morphotype codes see Table 1

\begin{tabular}{|c|c|c|c|c|c|c|}
\hline & \multirow[t]{2}{*}{ Code } & \multicolumn{2}{|c|}{ Cryptomonads } & \multirow[b]{2}{*}{$\mathrm{STH}$} & \multirow{2}{*}{$\begin{array}{c}\text { Non-cryptomonad } \\
\mu \text { ALG }\end{array}$} & \multirow[b]{2}{*}{$\mathrm{CHL}$} \\
\hline & & $\mathrm{RHO}$ & CRY & & & \\
\hline \multirow[t]{4}{*}{ Interception feeders } & HIS & $-0.33(0.003)$ & $0.23(0.04)$ & ns & ns & ns \\
\hline & ASK & ns & $0.32(0.004)$ & ns & ns & ns \\
\hline & BAL & $0.29(0.01)$ & $0.27(0.02)$ & ns & ns & ns \\
\hline & UF & $0.24(0.03)$ & $0.24(0.03)$ & ns & $\mathrm{ns}$ & ns \\
\hline \multirow[t]{5}{*}{ Filter feeders } & PD & $0.35(0.002)$ & ns & $\mathrm{ns}$ & ns & ns \\
\hline & OLI & ns & ns & $0.28(0.01)$ & ns & ns \\
\hline & RLAC & ns & ns & ns & ns & ns \\
\hline & STR & ns & ns & ns & ns & ns \\
\hline & TIN & ns & ns & ns & $0.25(0.03)$ & ns \\
\hline Interception feeders & & \multicolumn{2}{|c|}{$0.28(0.01)$} & \multicolumn{3}{|c|}{ ns } \\
\hline Filter feeders & & \multicolumn{2}{|c|}{$\mathrm{ns}$} & \multicolumn{3}{|c|}{$0.25(0.03)$} \\
\hline
\end{tabular}

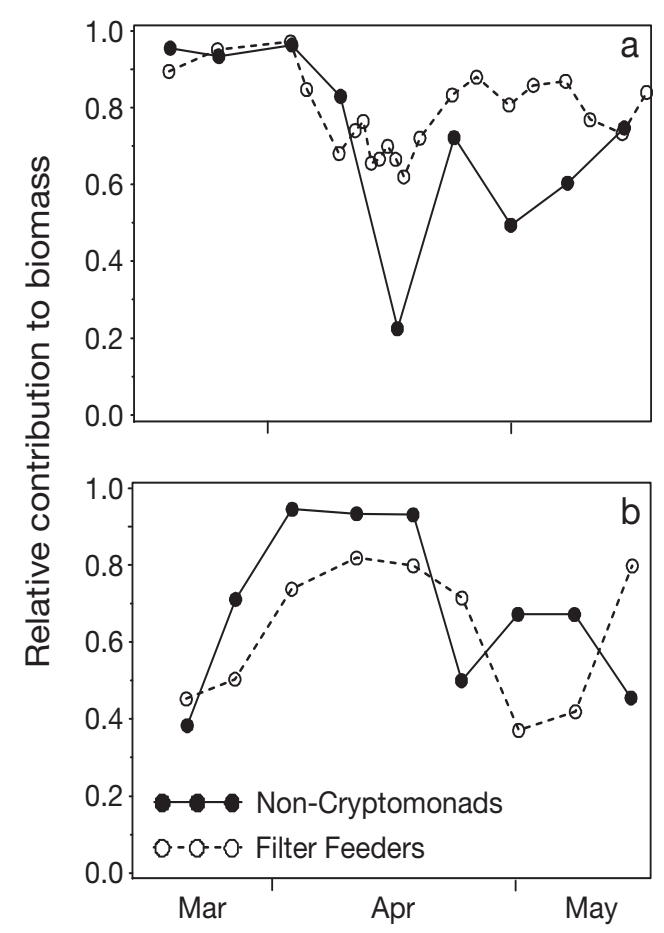

Fig. 5. Relative contribution of non-cryptomonads to total edible phytoplankton biomass and of filter feeders to total ciliate biomass in (a) 1991 and (b) 1996 during the spring bloom (mid-March until mid-May). The relative contribution of cryptomonads and interception feeders yields the reverse pattern

carnivorous ciliates (e.g. 1998) had mass developments prior to that of the daphnids (Fig. 7). The various predator groups exerted a fairly constant predation pressure on ciliates in late May/early June. The onset of the ciliate decline was related to the date when total predator biomass exceeded approximately $1500 \mathrm{mg} \mathrm{C}$ $\mathrm{m}^{-2}\left(\mathrm{r}^{2}=0.55, \mathrm{p}<0.01, \mathrm{n}=12\right.$; Fig. 6). However, daph- nids were consistently the dominant predators of ciliates at the day of minimum ciliate biomass during the clear-water phase, except in 1987. The onset of the ciliate decline was also correlated with the average water temperature $(0$ to $20 \mathrm{~m})$ in May $(\mathrm{r}=0.68, \mathrm{p}<0.05, \mathrm{n}=$ $11)$, as was the biomass of daphnids ( $r=0.83, p<0.01$, $\mathrm{n}=11$ ) in May.

Spring ciliate development was characterised by the large temporal variability of its onset (SD [day of the year] = $15 \mathrm{~d}$ ) and a smaller one of its termination SD [day of the year] = $11 \mathrm{~d}$ ) and its minimum (SD [day of the year] $=7 \mathrm{~d}$ ). This implies that the duration of ciliate dominance in spring was largely controlled by the onset of ciliate growth, which, in turn, depended on the onset of the phytoplankton bloom (SD [day of the year $]=14 \mathrm{~d}$ ).

\section{DISCUSSION}

Various studies have investigated annual ciliate dynamics in temperate lakes, but we were the first to examine in detail a period of coexistence of small algae and ciliates, when the under-water light climate is already suitable to support substantial net growth of phytoplankton or primary production, but biomass of crustaceans is still low.

\section{Ciliate spring growth}

The onset of ciliate spring development depended on that of phytoplankton and on vertical mixing intensity, but not on lake temperature. Throughout the $12 \mathrm{yr}$ of investigations, ciliate biomass started to increase shortly after an increase in phytoplankton biomass. 

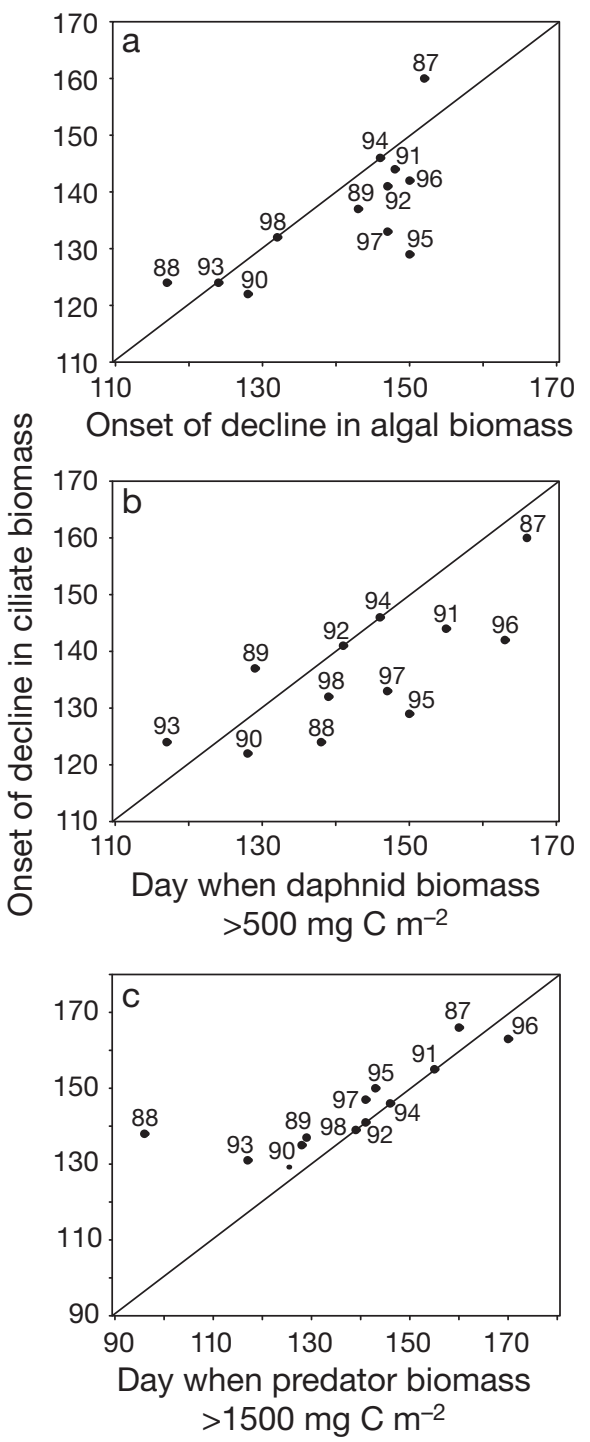

Fig. 6. Relationship between the day of the year of the onset of the decline in ciliate biomass and (a) the onset of the decline in edible algal biomass, (b) the day of the year when daphnid biomass reached $500 \mathrm{mg} \mathrm{C} \mathrm{m}^{-2}$ and (c) when total predator biomass reached $1500 \mathrm{mg} \mathrm{C} \mathrm{m}^{-2}$. The solid line represents 1:1

Due to their short generation times, ciliates responded immediately to increases in their food source. This is in agreement with earlier works from Lake Constance (Weisse et al. 1990, Müller et al. 1991) and with field observations from other waters (Johansson et al. 2004, Sonntag et al. 2006).

The dependence of ciliates on vertical mixing intensity is presumably attributable to 2 effects: (1) epilimnetic ciliate abundance is directly reduced by deep vertical mixing, as surface concentrations are generally higher than at greater depth; (2) ciliate growth declines under pronounced vertical mixing as the algal concentration in the surface layer is reduced by dilution as well (Gaedke et al. 1998a, Tirok \& Gaedke 2007).
Ciliate biomass and growth in March were unrelated to lake temperature. Given sufficient food, ciliate biomass increased in situ at rates of 0.05 to $0.10 \mathrm{~d}^{-1}$ (mean $0.065 \pm 0.019 \mathrm{~d}^{-1} \mathrm{SD}$ ), even at low temperatures (4 to $8^{\circ} \mathrm{C}$ ), which agrees with other studies. A numerical response of several ciliate species to peaks in picocyanobacteria, centric and pennate diatoms and cryptophytes was observed at temperatures of 4 to $5^{\circ} \mathrm{C}$ in Lake Traunsee (Austria) (Sonntag et al. 2006). This stands in contrast to the population development of crustaceans, which was tightly associated with spring warming (Straile 2000, Lee et al. 2003). As for other zooplankton, maximum growth rates of ciliates were shown to be temperature dependent in the laboratory (Finlay 1977, Müller \& Geller 1993). Nevertheless, laboratory-derived growth rates at in situ temperatures (0.03 to $0.46 \mathrm{~d}^{-1}$ at $5.5^{\circ} \mathrm{C}$ in 4 different ciliate species; Müller \& Geller 1993) are at least as high as the observed biomass increase.

In many waters, growth of phytoplankton, ciliates and crustaceans is temporally coupled as the improvement of growth conditions for phytoplankton is often combined with a warming of the water body, e.g. ice-off induced by increasing temperature entails a sufficient underwater light climate as well as a rapid warming (Weyhenmeyer et al. 1999, Gerten \& Adrian 2000). Temperature-dependent stratification in deep waters has the same effect (e.g. Peeters et al. 2007). Nevertheless, the relatively high growth potential of ciliates at low temperatures can result in a temporal decoupling of ciliate dynamics from crustacean dynamics during periods of less intense mixing and low water temperature in deep waters. This was found in some years in Lake Constance when an extended spring bloom of algae and ciliates was observed prior to crustacean mass development. Accordingly, during years with higher water temperatures, short protozoan blooms and an earlier development of daphnids and of the clear-water phase were observed (Straile 2000, 2002).

Climate change is likely to reduce the frequency and duration of the periods when ciliates are the most important algal grazers, since higher water temperatures will promote crustacean growth. In addition, the expected increase in cyclone activity associated with an increase in the occurrence of strong wind events (Leckebusch \& Ulbrich 2004), which intensify vertical mixing during spring prior to stable stratification, may also reduce the decoupling of ciliate and crustacean development. During years with continuous intense vertical mixing during February/March, we observed a late phytoplankton and ciliate bloom, whereas crustaceans developed earlier than in years in which calm periods alternated with turbulent ones (Tirok \& Gaedke 2006). 


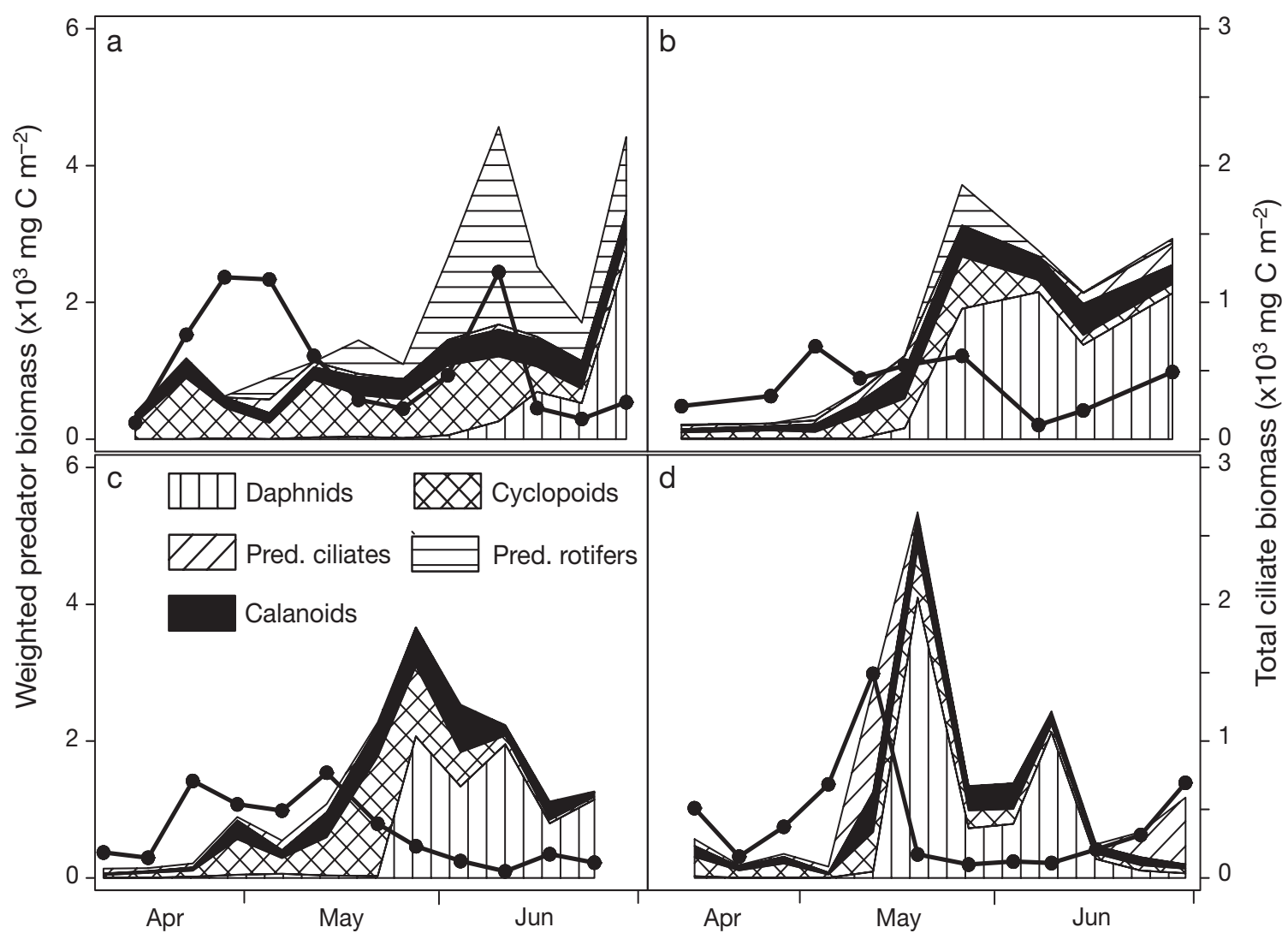

Fig. 7. Spring development of ciliate biomass ( $\bullet-$, right $y$-axis) and of potential ciliate (intraguild) predators (left $y$-axis): daphnids, cyclopoid copepods, calanoid copepods, predacious ciliates and predacious rotifers in (a) 1987, (b) 1994, (c) 1997 and (d) 1998. Relative and absolute importance of ciliate predators during the onset of ciliate decline towards the clear-water phase varies greatly among years (e.g. 1987: rotifers, 1994: daphnids, 1997: copepods). Biomass of predacious ciliates and rotifers was weighted by a factor of 2.5 to account for the higher weight-specific metabolic activity of these smaller organisms as compared to the crustaceans

\section{Ciliate spring bloom and species shifts}

The shape of the algal and ciliate spring bloom exhibited large interannual variability. In some years, it was characterised by a unimodal curve, whereby a steep increase in algal and subsequently ciliate biomass resulted in a distinct peak, which was followed by a rapid decline (Fig. 1). The increase depended on the vertical mixing intensity, and the decline was attributed to grazing by larger zooplankton, which represented external forces to the algal and ciliate communities. In other years, the spring bloom lasted over an extended period of time and had several peaks prior to stable stratification, as it was periodically interrupted by intermittent mixing. A similar pattern was observed for phytoplankton in marine systems characterised by unstable stratification (Townsend et al. 1992, Tian et al. 2003, Waniek 2003). During such extended spring blooms, which lasted up to $9 \mathrm{wk}$, i.e. approximately 15 to 30 generations, competitive species inter- actions, i.e. internal forces, may have affected the community composition more strongly than external forces, which determined the onset and termination of the bloom. For example, we found an alternation between filter and interception feeders during years with long-lasting spring blooms (e.g. 1991, 1996). These shifts may be attributable to bottom-up effects as they went along with alternations in the relative importance of cryptomonads and non-cryptomonads. Ciliates are known to feed selectively on small phytoplankton (Verity 1991, Hamels et al. 2004). An interception feeder (Balanion planktonicum) from Lake Constance showed a strong negative selection for diatoms (Stephanodiscus parvus), whereas a filter feeder (Strobilidium lacustris) ingested this small centric diatom (Müller \& Schlegel 1999). Many ciliate species cannot grow on a diatom diet, thus the nutritional value of diatoms for ciliates seems to be generally low (Gifford 1985, Skogstad et al. 1987). A number of diatom species are known to release reactive alde- 
hydes when broken (Pohnert et al. 2002), which negatively influence the reproduction of herbivorous copepods (Ban et al. 1997). However, some ciliate species grew well by utilising diatoms or were even specialised on diatoms as their only prey (Gifford 1985, Skogstad et al. 1987). That is, the utilisation of different prey algae by ciliates is highly species specific. Filter feeders may benefit from a high quantity of a mixed algal diet in Lake Constance during spring. This feeding behaviour stands in contrast to that of interception feeders, which feed almost exclusively on cryptomonads. These 2 types of feeding behaviour may represent 2 different strategies to meet the trade-off between food quantity and quality. Filter feeders exploit a larger food quantity with lower quality, whereas interception feeders rely on high quality, but less-abundant resources. Total edible algal biomass reached values between approximately 200 and $2000 \mathrm{mg} \mathrm{C} \mathrm{m}^{-2}$, i.e.

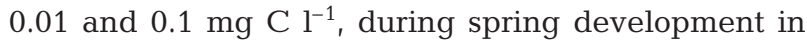
Lake Constance, which is known to be within the range of threshold food values for positive growth of many ciliate species (Weisse 2006). That is, high-quality cryptomonads often have biomasses below the laboratory-derived threshold values of ciliates, especially during periods when small diatoms dominate edible algal biomass.

Selective predation by a temporally variable predator community may also contribute to the alterations in ciliate community composition, as ciliate species differ in their susceptibility and their defence strategies to predators and the different groups of predators (rotifers, copepods, cladocerans) and their life stages differ in their prey spectra (Wiackowski et al. 1994, Jack \& Gilbert 1997, Mohr \& Adrian 2002). However, it is unlikely that this is the dominant mechanism in Lake Constance during the ciliate spring bloom when copepods were the only abundant predators ( 700 mg $\mathrm{C} \mathrm{m}^{-2}$ on average in April 1987 to 1998). They were still hampered in their activity by low temperatures (5 to $<12^{\circ} \mathrm{C}$ ), which also implies that their generation times were too long to track changes in ciliate composition. We observed ciliate biomass increases even at a high biomass of copepods. That is, copepods may influence overall ciliate community composition, but hardly the species shifts observed at a time scale of 10 to $20 \mathrm{~d}$.

\section{Termination of the spring bloom}

A strong bottom-up effect on the onset of the decline of ciliate biomass towards the clear-water phase is unlikely for most years, as ciliate biomass declined prior to the decline of its dominant prey. Several studies showed that large grazers such as clado- cerans, copepods and rotifers may have a substantial negative impact on ciliate abundance, due to direct predation and/or exploitative and interference competition (Jack \& Gilbert 1997, Burns \& Schallenberg 2001, Mohr \& Adrian 2002, Sonntag et al. 2006). Daphnids exerted pronounced intraguild predation on ciliates when their biomass surpassed 25-50 mg C $\mathrm{m}^{-3}$ (corresponding to $500-1000 \mathrm{mg} \mathrm{C} \mathrm{m}^{-2}$ in a $20 \mathrm{~m}$ water column as considered in this study) (Jürgens 1994, Gaedke \& Straile 1998, Tittel et al. 1998, Weisse \& Müller 1998). They dominated the crustacean zooplankton during the clear-water phase and in summer, but presumably did not represent the main reason for the onset of the ciliate decline in Lake Constance, as ciliates mostly declined before the daphnid biomass surpassed $500 \mathrm{mg} \mathrm{C} \mathrm{m} \mathrm{m}^{-2}$. This agrees with the finding that calanoid and cyclopoid copepods suppressed ciliates more strongly than cladocerans (Adrian \& Schneider-Olt 1999, Burns \& Schallenberg 2001). However, a significant relationship between both groups of copepods and the beginning of the ciliate decline was not found. In most years, ciliates declined when several predator groups were present (Fig. 6), exerting a fairly regular predation pressure on the entire ciliate community in late May/early June prior to the daphnid mass abundance; a late development of 1 intraguild predator (i.e. daphnids, predating on ciliates and competing with them for phytoplankton) was compensated by the increased occurrence of other predator groups. This pattern was also observed in the algal community (Bergquist et al. 1985, Tittel et al. 1998, Tirok \& Gaedke 2006), where micro-zooplankton exclusively grazing on small algae did not cause a clear-water phase. The decline in the ciliate community was also related to water temperature, which is explicable by the tight connection of crustacean development and feeding activity with temperature (Straile 2000, Lee et al. 2003). In addition, cyst formation as a strategy to avoid grazing by copepods may contribute to the decline in ciliate biomass (e.g. Müller \& Wünsch 1999).

The remarkably high interannual variability in the ciliate bloom duration arises from the fact that the beginning and the termination of ciliate spring growth were controlled by different and largely independent factors (i.e. episodic wind events/vertical mixing and temperature-sensitive predators). In years with an early or late onset of ciliate growth no further shift in the subsequent successional events was observed. In contrast, memory effects were observed for other populations. For example, after mild winters a shift towards an early start and termination of daphnid spring development was observed in Lake Constance and Lake Müggelsee, Germany (Straile \& Adrian 2000) and in Bautzen Reservoir, Germany (Benndorf et al. 
2001). This early termination of daphnid mass development after an early onset of growth was attributable to an early overexploitation of food. This pattern was not observed in ciliates, which coexisted with their prey for several weeks. Their more selective feeding behaviour presumably induced cycles in algal and ciliate species composition.

\section{CONCLUSIONS}

To conclude, ciliates responded directly to pulses of their prey even at low temperatures and thus utilised transient favourable growth conditions. They dominated the grazing pressure on phytoplankton in Lake Constance during winter and spring, as long as low temperatures hampered metazoan herbivores. This advantage and thus their dominance may be reduced by the ongoing climate change. During the spring bloom, interacting short-term species shifts within the edible phytoplankton and the algivorous ciliate community dominated over seasonally directed changes.

Acknowledgements. We thank S. Hochstädter for contribution to data analysis and R. Adrian, D. Straile and G. Weithoff for helpful remarks on the manuscript. H. Müller initiated the long-term measurements on ciliates. K.T. was funded by the German Research Foundation (DFG) within the Priority Program 1162 'The impact of climate variability on aquatic ecosystems (AQUASHIFT)' (GA 401/7-1). Data acquisition was, for the most part, performed within the Special Collaborative Program (SFB) 248 'Cycling of Matter in Lake Constance' supported by the DFG.

\section{LITERATURE CITED}

Adrian R, Schneider-Olt B (1999) Top-down effects of crustacean zooplankton on pelagic microorganisms in a mesotrophic lake. J Plankton Res 21:2175-2190

Ban SH, Burns C, Castel J, Chaudron Y and 19 others (1997) The paradox of diatom-copepod interactions. Mar Ecol Prog Ser 157:287-293

Bäuerle E, Ollinger D, Ilmberger J (1998) Some meteorological, hydrological and hydrodynamical aspects of Upper Lake Constance. Arch Hydrobiol Spec Iss Adv Limnol 53:31-83

Benndorf J, Kranich J, Mehner T, Wagner A (2001) Temperature impact on the midsummer decline of Daphnia galeata: an analysis of long-term data from the biomanipulated Bautzen Reservoir (Germany). Freshw Biol 46: 199-211

Bergquist AM, Carpenter SR, Latino JC (1985) Shifts in phytoplankton size structure and community composition during grazing by contrasting zooplankton assemblages. Limnol Oceanogr 30:1037-1045

Burns CW, Schallenberg M (2001) Calanoid copepods versus cladocerans: consumer effects on protozoa in lakes of different trophic status. Limnol Oceanogr 46:1558-1565

Edwards M, Richardson AJ (2004) Impact of climate change on marine pelagic phenology and trophic mismatch Nature 430:881-884

Finlay BJ (1977) Dependence of reproductive rate on cell-size and temperature in freshwater ciliated protozoa. Oecologia 30:75-81

Gaedke U (1998) Functional and taxonomical properties of the phytoplankton community of large and deep Lake Constance: interannual variability and response to reoligotrophication (1979-1993). Arch Hydrobiol Spec Issu Adv Limnol 53:119-141

Gaedke U, Straile D (1994) Seasonal-changes of trophic transfer efficiencies in a plankton food-web derived from biomass size distributions and network analysis. Ecol Model 75:435-445

Gaedke U, Straile D (1998) Daphnids: keystone species for the pelagic food web structure and energy flow. A body sizerelated analysis linking seasonal changes at the population and ecosystem levels. Arch Hydrobiol Spec Iss Adv Limnol 53:587-610

Gaedke U, Wickham SA (2004) Ciliate dynamics in response to changing biotic and abiotic conditions in a large, deep lake (Lake Constance). Aquat Microb Ecol 34:247-261

Gaedke U, Ollinger D, Kirner P, Bäuerle E (1998a) The influence of weather conditions on the seasonal plankton development in a large and deep lake (L. Constance). III. The impact of water column stability on spring algal development. In: George DG, Jones JG, Puncochár P, Reynolds CS, Sutcliffe DW (eds) Management of lakes and reservoirs during global climate change. Kluwer Academic Publishers, Dordrecht, p 71-84

Gaedke U, Seifried A, Kümmerlin R (1998b) The influence of weather conditions on the seasonal plankton development in a large and deep lake (L. Constance). I. The impact of irradiance, air temperature and wind on the algal spring development in a large and deep lake (L. Constance). In: George DG, Jones JG, Puncochár P, Reynolds CS, Sutcliffe DW (eds) Management of lakes and reservoirs during global change. Kluwer Academic Publishers, Dordrecht, p 39-55

Gaedke U, Ollinger D, Bäuerle E, Straile D (1998c) The impact of interannual variability in hydrodynamic conditions on the plankton development in Lake Constance in spring and summer. Arch Hydrobiol Spec Iss Adv Limnol 53:565-585

Gaedke U, Hochstädter S, Straile D (2002) Interplay between energy limitation and nutritional deficiency: empirical data and food web models. Ecol Monogr 72:251-270

Gerten D, Adrian R (2000) Climate-driven changes in spring plankton dynamics and the sensitivity of shallow polymictic lakes to the North Atlantic Oscillation. Limnol Oceanogr 45:1058-1066

Gifford DJ (1985) Laboratory culture of marine planktonic oligotrichs (Ciliophora, Oligotrichida). Mar Ecol Prog Ser 23:257-267

Giorgi F, Bi XQ, Pal J (2004) Mean, interannual variability and trends in a regional climate change experiment over Europe. II. Climate change scenarios (2071-2100). Clim Dyn 23:839-858

Hamels I, Mussche H, Sabbe K, Muylaert K, Vyverman W (2004) Evidence for constant and highly specific active food selection by benthic ciliates in mixed diatom assemblages. Limnol Oceanogr 49:58-68

Häse C, Gaedke U, Seifried A, Beese B, Tilzer MM (1998) Phytoplankton response to re-oligotrophication in large and deep Lake Constance: photosynthetic rates and chlorophyll concentrations. Arch Hydrobiol Spec Iss Adv Limnol 53:159-178 
IPCC (Intergovernmental Panel on Climate Change) (2001) Climate Change 2001: impacts, adaptation and vulnerability. In: McCarthy JJ, Canziano OF, Leary NA, Dokken DJ, White KS (eds) Contribution of Working Group II to the third assessment report of IPCC. Cambridge University Press, Cambridge

Jack JD, Gilbert JJ (1997) Effects of metazoan predators on ciliates in freshwater plankton communities. J Eukaryot Microbiol 44:194-199

Johansson M, Gorokhova E, Larsson U (2004) Annual variability in ciliate community structure, potential prey and predators in the open northern Baltic Sea proper. J Plankton Res 26:67-80

Jürgens K (1994) Impact of Daphnia on planktonic microbial food webs - a review. Mar Microb Food Webs 8:295-324

Knisely K, Geller W (1986) Selective feeding of four zooplankton species on natural lake phytoplankton. Oecologia 69: 86-94

Kümmerlin RE (1991) Long term development of phytoplankton in Lake Constance. Verh Int Verein Limnol 24: 826-830

Leckebusch GC, Ulbrich U (2004) On the relationship between cyclones and extreme windstorm events over Europe under climate change. Global Planet Change 44: 181-193

Lee HW, Ban S, Ikeda T, Matsuishi T (2003) Effect of temperature on development, growth and reproduction in the marine copepod Pseudocalanus newmani at satiating food condition. J Plankton Res 25:261-271

Mohr S, Adrian R (2002) Effects of Brachionus calyciflorus and Brachionus rubens on a manipulated freshwater microbial community. J Plankton Res 24:25-31

Müller H (1989) The relative importance of different ciliate taxa in the pelagic food web of Lake Constance. Microb Ecol 18:261-273

Müller H, Geller W (1993) Maximum growth-rates of aquatic ciliated protozoa - the dependence on body size and temperature reconsidered. Arch Hydrobiol 126:315-327

Müller H, Schlegel A (1999) Responses of three freshwater planktonic ciliates with different feeding modes to cryptophyte and diatom prey. Aquat Microb Ecol 17:49-60

Müller H, Wünsch C (1999) Seasonal dynamics of cyst formation of pelagic strombidiid ciliates in a deep prealpine lake. Aquat Microb Ecol 17:37-47

Müller H, Schöne A, Pinto-Coelho RM, Schweizer A, Weisse $\mathrm{T}$ (1991) Seasonal succession of ciliates in Lake Constance. Microb Ecol 21:119-138

Neuer S, Cowles TJ (1994) Protist herbivory in the Oregon upwelling system. Mar Ecol Prog Ser 113:147-162

Peeters F, Straile D, Lorke A, Ollinger D (2007) Turbulent mixing and phytoplankton spring bloom development in a deep lake. Limnol Oceanogr 52:286-298

Pohnert G, Lumineau O, Cueff A, Adolph S, Cordevant C, Lange M, Poulet S (2002) Are volatile unsaturated aldehydes from diatoms the main line of chemical defence against copepods? Mar Ecol Prog Ser 245:33-45

Samuelsson K, Berglund J, Andersson A (2006) Factors structuring the heterotrophic flagellate and ciliate community along a brackish water primary production gradient. J Plankton Res 28:345-359

Skogstad A, Granskog L, Klaveness D (1987) Growth of freshwater ciliates offered planktonic algae as food. J Plankton Res 9:503-512

Sommer U, Gliwicz ZM, Lampert W, Duncan A (1986) The PEG-model of seasonal succession of planktonic events in fresh waters. Arch Hydrobiol 106:433-471

Sommer U, Gaedke U, Schweizer A (1993) The 1st decade of oligotrophication of Lake Constance. 2. The response of phytoplankton taxonomic composition. Oecologia 93: 276-284

Sonntag B, Posch T, Klammer S, Teubner K, Psenner R (2006) Phagotrophic ciliates and flagellates in an oligotrophic, deep, alpine lake: contrasting variability with seasons and depths. Aquat Microb Ecol 43:193-207

Straile D (2000) Meteorological forcing of plankton dynamics in a large and deep continental European lake. Oecologia 122:44-50

Straile D (2002) North Atlantic Oscillation synchronizes foodweb interactions in central European lakes. Proc R Soc Lond Ser B 269:391-395

Straile D, Adrian R (2000) The North Atlantic Oscillation and plankton dynamics in two European lakes-two variations on a general theme. Global Change Biol 6: $663-670$

Straile D, Geller W (1998a) The response of Daphnia to changes in trophic status and weather patterns: a case study from Lake Constance. ICES J Mar Sci 55:775-782

Straile D, Geller W (1998b) Crustacean zooplankton in Lake Constance from 1920 to 1995: response to eutrophication and re-oligotrophication. Arch Hydrobiol Spec Iss Adv Limnol 53:255-274

Straile D, Livingstone DM, Weyhenmeyer GA, George DG (2003) The response of freshwater ecosystems to climate variability associated with the North Atlantic Oscillation. In: Hurrell JW, Kushnir Y, Ottersen G, Visbeck M (eds) The North Atlantic Oscillation. Climatic significance and environmental impact. AGU Monographs, Washington, DC, p 263-279

Tian RC, Deibel D, Thompson RJ, Rivkin RB (2003) Modeling of climate forcing on a cold-ocean ecosystem, Conception Bay, Newfoundland. Mar Ecol Prog Ser 262:1-17

Tilzer MM, Beese B (1988) The seasonal productivity cycle of phytoplankton and controlling factors in Lake Constance. Schweiz Z Hydrol 50:1-39

Tirok K, Gaedke U (2006) Spring weather determines the relative importance of ciliates, rotifers and crustaceans for the initiation of the clear-water phase in a large, deep lake. J Plankton Res 28:361-373

Tirok K, Gaedke U (2007) The effect of irradiance, vertical mixing and temperature on spring phytoplankton dynamics under climate change: long-term observations and model analysis. Oecologia 150:625-642

Tittel J, Zippel B, Geller W, Seeger J (1998) Relationships between plankton community structure and plankton size distribution in lakes of northern Germany. Limnol Oceanogr 43:1119-1132

Townsend DW, Keller MD, Sieracki ME, Ackleson SG (1992) Spring phytoplankton blooms in the absence of vertical water column stratification. Nature 360:59-62

Verity PG (1991) Feeding in planktonic protozoans — evidence for nonrandom acquisition of prey. J Protozool 38:69-76

Waniek JJ (2003) The role of physical forcing in initiation of spring blooms in the northeast Atlantic. J Mar Syst 39: 57-82

Weisse T (2006) Freshwater ciliates as ecophysiological model organisms - lessons from Daphnia, major achievements, and future perspectives. Arch Hydrobiol 167: 371-402

Weisse T, Müller H (1998) Planktonic protozoa and the microbial food web in Lake Constance. Arch Hydrobiol Spec Iss Adv Limnol 53:223-254

Weisse T, Müller H, Pinto-Coelho RM, Schweizer A, Springmann D, Baldringer G (1990) Response of the microbial loop to the phytoplankton spring bloom in a large pre- 
alpine lake. Limnol Oceanogr 35:781-794

Weyhenmeyer GA, Blenckner T, Pettersson K (1999) Changes of the plankton spring outburst related to the North Atlantic Oscillation. Limnol Oceanogr 44:1788-1792

Wiackowski K, Brett MT, Goldman CR (1994) Differential-

Editorial responsibility: Klaus Jürgens,

Rostock, Germany effects of zooplankton species on ciliate community structure. Limnol Oceanogr 39:486-492

Winder M, Schindler DE (2004) Climate change uncouples trophic interactions in an aquatic ecosystem. Ecology 85: $2100-2106$

Submitted: December 18, 2006; Accepted: July 7, 2007

Proofs received from author(s): August 16, 2007 